Original Article

\title{
The Ticket to Heaven: A Spiritual Resource for Coping with Disability
}

\author{
Osman Hatun ${ }^{1}$ \\ Zeynep İnce ${ }^{3}$
}

\author{
Fazilet Yavuz-Birben ${ }^{2}$ \\ Gülay Kalkan-Yeni ${ }^{4}$
}

\begin{abstract}
This study was conducted to investigate how parents of disabled people deal with the phenomenon of disability, their hardships in accepting the process, and support mechanisms used to deal with the situation. The phenomenological research design was used and 17 in-depth interviews were conducted with parents. Of the interviewed parents' children, five of them have mental retardation, five have a physical disability, five have both a mental and physical disability, and two have autism spectrum disorder. The obtained data were phenomenologically analyzed with the support of MAXQDA 11. Data were examined in three general categories: difficulty of the process, coping resources, and spiritual coping. Of these categories, difficulty of the process and coping resources are thought to allow for better understanding of spiritual coping, the focus of the study. The sub-themes of shock/collapse, not attributing, fear of losing the child, disappointment, self-blame, loneliness, lack of paternal support, negative environmental effects, concern for the future, and despair is evaluated under the theme of difficulty of the process. The sub-themes of expert support, family support, environmental care, rationalizing, hope, following daily routines, blaming, and unable to be apart from the child is evaluated under the theme of coping resources. The core category of the research, spiritual coping resources, is examined under the categories of acceptance (accepting what comes from God and destiny), giving spiritual meaning (being tested, repentance, fear of God, and being an entrustment from God), and trust in God (resignation, gratitude, and prayer). Recommendations have been presented based on the results of the research.
\end{abstract}

Keywords

Parents of children with disability $\bullet$ Coping with disability $\bullet$ Spiritual coping $\bullet$ Spiritual counseling

\section{Cennet Bileti: Engellilik Olgusuyla Baş Etmede Manevi Bir Kaynak}

Öz

Ebeveynlerin engellilik olgusu ile nasıl başettiklerini, kabullenme sürecinde yaşadıkları güçlükleri ve baş etmelerinde kullandıkları destek mekanizmalarını incelemeyi hedefleyen bu çalışmada fenomenolojik desen kullanılarak 17 ebeveynle derinlemesine mülakat gerçekleştirilmiştir. Görüşme yapılan ebeveynlerin çocuklarının beşi zihinsel, beşi bedensel, beşi hem zihinsel hem de bedensel engelli, iki kişinin çocuğu da otizm tanılıdır. Elde edilen veriler MAXQDA 11 programı desteğiyle fenomenolojik analize tabi tutulmuştur. Veriler; sürecin zorluğu, başetme kaynakları ve manevi başetme olarak üç genel kategoride incelenmiştir. Bu kategorilerden sürecin zorluğu ve başetme kaynakları temalanı çalışmanın odak noktası olan manevi başetme fenomenini daha iyi anlamak için ele alınmıștır. Bu kategorilerden sürecin zorluğu; "şok-yıkılmak", "konduramamak", "çocuğu kaybetme korkusu", "hayal kırıklığı", "kendini suçlama”, "yalnızlık”, "babanın desteğinin yetersizliği”, "çevrenin olumsuz etkisi”, "gelecek kaygısı" ve "çaresizlik" temalarında; başetme kaynakları, "uzman desteği", "aile desteği", "çevre desteği", "rasyonalize etme", "umut", "rutinleri sürdürme", "suçlama" ve "çocuktan ayrışamamak" temalarında değerlendirilmiştir. Çalışmanın merkezini oluşturan "manevi başetme kaynakları" ise, "kabullenme" üst başlığılla "Allah’tan gelene razı olmak" ve "kader", "manevi olarak anlamlandırma" bașlığı altında "imtihan", "tevbe", "Allah Korkusu" ve "Allah’ın emaneti", "Allah’a yaslanmak" bașlığı altında "tevekkül”, "şükür" ve "dua" temalarında incelenmiş ve araştırmanın sonuçları doğrultusunda öneriler sunulmuştur.

Anahtar Kelimeler

Engelli aileleri • Engelle başetme $\bullet$ Kabullenme • Manevi başetme • Manevi rehberlik

1 Correspondence to: Osman Hatun, Fatih Guidance and Research Center, Istanbul 34116 Turkey.

Email: osmanhatun@hotmail.com

2 Educational Sciences Department, Institute of Social Sciences, Yıldız Technical University, Istanbul 34200 Turkey.

Email: faziletyavuz@hotmail.com

3 Bagcılar Municipality Rehabilitation Center, Istanbul34200 Turkey. Email: zince42@hotmail.com

4 Umraniye Guidance and Research Center, Istanbul 34775 Turkey. Email: gulaykalkan@gmail.com

Citation: Hatun, O., Yavuz Birben, F., İnce, Z., \& Kalkan Yeni, G. (2016). The ticket to Heaven: A spiritual resource for coping with disability. Spiritual Psychology and Counseling, 1, 209-235. http://dx.doi.org/10.12738/spc.2016.2.0013 
Being diagnosed with a disability is a traumatic life experience when considering how it affects the lives, feelings, and behaviors of family members. Many families want to have and raise a normal child, and such families hold expectations and hopes when it comes to the future of their children. On the contrary, families with disabled children might experience dramatic changes in their social lives, family plans, lives, economic conditions, emotional states, and expectations for the future (O'Connell, O'Halloran, \& Doody, 2013).

Schild (1971), Fortier and Wanlass (1984), Eripek (1996), and Akkök (1997) put forth that starting from the moment when a family learns they have a disabled child, emotional and adaptive processes generally go through the following phases. In the beginning, families predominantly go through a phase of shock accompanied by feelings related to denial, affliction, grief, and depression after having had to deal with a surprising situation, different from their dreams and expectations. First, parents are in a state of denial. However, after finding out that nothing will change over time, they start to feel grief and depression, accompanied by more complicated feelings such as anger, guilt, and shame. Following these phases, the phase of acknowledgement and restructuring comes into play, wherein parents seek a solution, do their best for taking care of their child, and monitor their treatment and education processes (as cited in Şarda ğ, 2010). Additionally, the patients' interviews showed that health professionals' wording at the moment of initial diagnosis is quite significant (Ekşi et al., 2016).

Comparative studies examining families with disabled children have shown that mothers with disabled children have higher levels of depression, anxiety, and stress than mothers with non-disabled children (Uğuz, Toros, Yazgan-İnanç, \& Çolakkadıoğlu, 2004). Similarly, a study by Herken, Turan, Şenol, and Karaca (2000) concluded that parents of children with Down syndrome have significantly higher levels of depression compared to parents of healthy children. Their average behavioral scores for fatalism/spirituality are high while their average scores for addiction, escapism, social support, planning, and active behavior are low. In another study, having mentally disabled children was shown to result in anxiety, worry caused by wondering what will happen to their children when they die, fatigue, blaming the other parent, and divorce as a last resort. Additionally, fathers were found to be less inclined than mothers to care for their disabled children; mothers see their disabled child as a part of themselves and that having a disabled child fosters relationships among family members (Sevim, 2011).

Families with disabled children express concern over the lack of awareness in society regarding disabilities, and that adequate sensitivity on this matter is not displayed (Sevim, 2011). Families with disabled children feel alone in society, and 
both their quality of life and health conditions are poor. As mentioned above, mothers are the ones generally responsible for the care and education of disabled children, and they do not receive adequate support from their partners. In a study examining mothers with disabled children, they were found to often feel abandoned, lonely, and isolated from social life; they expressed a sense of disappointment, feeling that their pain went unnoticed throughout this period (O'Connell et al., 2013).

In a study carried out by Ergün and Ertem (2012), which aimed to identify the difficulties experienced by mothers with mentally disabled children, $38 \%$ were seen to feel grief; 43\%, anger; and 19\%, loneliness; 55\% were blamed by their partner's family for their child's disability. According to the results of the same study, only $30 \%$ of mothers had displayed a sense of acceptance for their children's disability.

Even though it is a well-known fact that parents with disabled children face difficulties caring for their children, the process becomes quite simpler when appropriate coping methods are used. Struggling to cope with the encountered difficulties is a process that affects both the individuals involved and their environment; it impacts, whether positively or negatively, the ideas and feelings about their quest to make sense of their lives. Based on the meaning attributed to the difficulties encountered, this process determines the life satisfaction, subjective well-being, and intensity that individuals will feel toward these difficulties (Durukan, Erdem, Tufan, \& Türkbay, 2010). Coping is defined by Iş1khan (2005) as struggling with the stress and problems that are encountered; by Muller and Spitz (2002), Lazarus (1990), Folkman and Moskowitz (2004) as the cognitive and behavioral effort devoted to overcoming stressful incidents and situations; and by Baltaş and Baltaş (1998) as minimizing losses by taking advantage of stress in order to facilitate development. Folkman and Lazarus (1980) suggested that there are two types of coping responses (problem-focused and emotion-focused), while Cox and Ferguson (1991) suggested that there are four types of coping, adding reappraisal and avoidance to the previous two types. Billings and Moos (1981), on the other hand, categorized three types of coping responses: active-behavioral, active-cognitive, and avoidance. Endler and Parker (1992) differentiated three coping types: emotion-oriented, task-oriented, and avoidant. In other studies, however, many support mechanisms have been suggested, such as informational, appraisal, material, tangible, emotional, social belonging, and daily care, which can all be divided into two: emotional-social support and instrumental support (Allen et al., 2000; Chen \& Thang, 1997; Cohen \& Wills, 1985; Dunst \& Trivette, 1986 as cited in Kaner, 2004).

Regarding coping responses, Kissinger (2006) established that people who are inclined to struggle prefer to seek solutions, gather information, and think about 
alternatives, whereas people who cannot struggle choose to leave their current environment with the hope of finding a source of distraction or prefer using avoidance methods such as denial. Skinner and Zimmer-Gembeck (2007) mentioned 12 coping strategies, some being problem solving, escape, seeking support, delegating, accommodating, negotiating, positive restructuring, and social isolation.

Traditional psychological studies focusing on the coping strategies of disabled individuals have mostly dealt with how individuals make sense of their own disability and how they integrate their disability into their concept of self. Most disabled individuals also choose to cope with their lack of fulfillment by highlighting some of the areas where they feel are adequate. In addition to these coping styles, some individuals adopt spiritual strategies to cope with their disability (Ekşi et al., 2016; Johnstone, Glass, \& Oliver, 2007). In a study examining the parents of children with autism, parents were revealed to use active-avoidance coping, problemfocused coping, positive coping, and religious coping strategies in order to overcome the stress experienced during the childrearing period. According to the results of the same study, there is also a relationship between parenting stress and mood (Hastings et al., 2005). According to a study carried out by Kara (2008) on families with mentally disabled children, $73.17 \%$ considered having a disabled child as the will of God, $87.7 \%$ prayed to God for their children, 96.4\% suggested that praying positively affected their psychological state, $59.6 \%$ thought they were destined to have a disabled child, $47.4 \%$ did not think their child was disabled because they had been guilty at some point in their lives, $66.7 \%$ suggested that they showed endurance in the face of difficulties with their children, $89.5 \%$ did not think God was unfair to them, 96.54\% did not think God didn't love them, and 94.7\% prayed to God for help while faced with difficult situations.

People are constantly trying to search for meaning in life and don't want to let this meaning slip by. This search is the reason why people manage to hold onto life and are willing to seek support when facing unbearable and traumatic situations or when they fail to find a solution to their problems. This support-seeking response results in turning to God and religion in an attempt to make sense of life and what they have gone through so far. The meanings people attribute to situations are more influential than the situation itself (Ayten, Göcen, Sevinç, \& Öztürk, 2012).

Karagöz (2010) found that parents of children with autism try to find religiously oriented answers to the question of "Why me?" and gave two different answers while trying to give meaning tothis, suggesting that religious beliefs are helpful in making sense of disability and religion is supportive in helping people cope with difficulties. Some parents said God chose them because He knew they could handle it, while 
others said God only gives successful and healthy children to those He loves, which results in negative affectivity. A study conducted by Gören (2015) also dealt with how families with disabled children spiritually made sense of their situation. In this study, parents were found to consider their disabled children as an entrustment from God to be kept safe and secure; felt as if they were blessed mothers; believed that their disabled children would provide them with a ticket to heaven; thought they were living with an angel in their home; felt proud to be parents of a heavenly child; and felt their children brought blessings to the house, luck to their lives, and peace to the family. According to the study, parents approved one or more of the above statements while some mothers believed all of them were correct.

Pargament and Brant (1998) put forth that whether or not religion proves to be an influential strategy for coping depends on the individual and the situation. While some studies suggest that religious coping responses are mostly used by women, elderly religious people, and people with lower socioeconomic and educational attainment, others indicate that religion is the most effective coping method in highly stressful situations. Religious coping responses can take a passive form for people who leave the rest to God or an active form for people who pray and perform religious rituals more frequently than before. Religious coping strategies can be problem-oriented such as the act of developing a specific problem-solving skill in order to overcome a barrier, or emotion-oriented such as gaining God's acceptance by taking advantage of the difficult situation.

According to Pargament's (2001) statements, religious coping theory shows how and the extent to which religion is used as a means of overcoming the problems of spiritual and physical daily life. This theory brings forward that individuals are found to have better physical and spiritual health when they adopt a positive approach based on collaboration with God in the problem-solving process, as well as its contrapositive. While Ayten (2012) identified a positive correlation between positive religious coping and life satisfaction, he suggested that the correlation between these two variables is not significant.

Even though the terms religion and spirituality have both mutually complementary and contradictory aspects, they are generally used interchangeably in the field. While spirituality is considered as an inner experience of the personal maturation process as influenced by meaning and intention, religion is accepted as an external experience of symbolic expressions related to prayer, tradition, doctrine, religious practices, beliefs, and ethical codes (Johnstone et al., 2007).

A great number of disabled people who hold religious beliefs and perform religious rituals in an active manner find their support by using religion as an effective argument 
for overcoming their problems while those who have no religious orientation do not believe religion will provide an effective argument in coping with disability. Some experts specify that health services and religious support should be kept separate while others indicate that religious support should not be ignored as long as it plays a functional role in individual coping responses. In a study investigating the relationship among religion, spirituality, and health in disabled individuals, religion and spirituality were found to positively correlate with mental and physical health, and religion and spirituality were considered to be two significant coping strategies for disabled individuals (Johnstone et al., 2007).

A study conducted by Stephen-Gallagher, Phillips, Lee, and Carroll (2015) dealing with the association between depression and spirituality in parents caring for children with developmental disabilities found spirituality to positively correlate with depression while social support was found to negatively relate to depression. The themes emerging from the interviews showed that spiritual/religious coping is a way of dealing with difficulty, and as a last resort, as a form of release from their situation. On the other hand, Tarakeshwar and Pargament (2001) found that positive religious coping related to better religious outcomes (e.g., closeness to God/church and spiritual growth) whereas negative religious coping was associated with greater depressive effects and poorer religious outcomes.

Religious coping can be positive or negative. Religious spiritual support, one of three sub-styles of positive coping, manifests itself in such a way that individuals feel they receive support from a higher power (e.g., believing the God will never leave them alone or allow something bad to happen to them); they have faith in God or believe that He will guide and help them cope with difficulties. Support from community or community leaders, the second sub-style of positive coping methods, refers to situations where the individual seeks support from a guide for coping with difficult situations. Some prefer receiving support from community leaders, whereas others choose to seek support from members of the community. These people derive support by performing religious practices in such places as temples, mosques, or churches. Positive attribution, the third coping style (hayra yormak in Turkish) is to believe that a situation is an indicator of good things to come, in turn facilitating the acceptance process. On the other hand, negative coping has two different styles. The first one is feeling alienated from God or the religious community; by having this disability, one believes they have been abandoned and left alone by God. This alienation creates feelings such as hopelessness and disappointment in the individual. The second one manifests itself in such a way that individuals consider the illness or disability to be a punishment from God, and they make negative religious reappraisals in the face of difficulties (Pargament \& Brant, 1998). 
In a study (Koenig, Pargament, \& Nielsen, 1998), elderly patients who had been hospitalized due to medical reasons and performed either religious or non-religious coping behaviors were compared in terms of health conditions. Negative methods of religious coping were found to be mildly associated with physical health and quality of life, whereas results of higher depression were found to be related to the reappraisal of being punished by God or evil forces and religious discontent.

On the other hand, expressions that included negative attitudes towards God, priests, and ecclesiastics were also stated to be associated with deeper depression and poorer quality of life. Positive religious coping behaviors related to mental wellbeing are defined as: considering God as a benefactor, cooperating with God, searching for communication with God, needing support from church and priests, and receiving faith-based aid from others (Koenig et al., 1998).

In a meta-analytical study analyzing studies that had examined the role of religion in coping with serious health problems, a considerable amount of people with a physical illness or disability were stated to have applied religious beliefs and practices in order to relieve stress, gain a sense of control, and find meaning, goals, and a sense of hope in life. Religious orientation is said to support psychological health by helping people recover from illness and cope with it more effectively, instead of being negatively affected as a result of stressful life experiences (Koenig, Larson, \& Larson, 2001). In his study examining the coping mechanisms that mothers of children with Down syndrome applied, Gören (2015) stated that mothers largely use religious coping methods that can be gathered around five themes: finding meaning, getting social support, focusing on postponement (patience), believing in divine justice, and practicing submission/cooperation.

In Miltiades and Pruchno's (2002) study, which investigated the relationship between race and religious coping in mothers of children with mental retardation, white mothers were found to use religious coping strategies more than black mothers; they also found a connection between religious coping and satisfaction from looking after a child with mental retardation. However, black mothers were revealed to feel more satisfied while caring for a child with mental retardation compared to white mothers, and as a result of inadequate sanitary conditions, they also felt the pressure of taking care of a child with mental retardation more intensely compared to white mothers.

Difficulties in the processes of caring for and educating children with mental retardation can cause mental health problems in mothers of children with a mental disability. Mirsaleh, Rezai, Khabaz, Afkhami-Ardekani, and Abdi (2011) compared the personality dimensions, religious tendencies, and coping strategies of mothers of children with mental retardation and mothers of children without mental retardation 
to help explain the general state of health of mothers who have children with and without mental-retardation. They revealed that the general health of mothers of children with a mental disability was worse and that religious tendencies and spirituality are positive predictors of a mother's general state of health.

Studies on people with disabilities and their relatives are found to usually focus on subjects such as difficulties related to the type and degree of disability, the psychological state of family members who care for the disabled person, family harmony, social support, sociocultural support mechanisms, and financial support mechanisms. However in this study, the focus has been on putting forward a qualitative study on the part that spiritual coping mechanism plays among the coping mechanisms of families of children with disabilities; this has been rarely encountered in the literature. This study is limited to the families of children with disabilities and families of children diagnosed with autism. The prevalence of the type of disability, the difficulties families face within the processes of care and education, and similarities in coping methods among other disability groups have an important influence on this limitation. As a result, the aim of this study is to identify what kind of spiritually-based support mechanisms are applied by parents of children with disabilities in the process of accepting the disability, as well as the impact of these spiritual support mechanisms on the process of accepting their child with a disability. In accordance with this study's aim, the research process intends to find answers to the following questions:

- What do parents feel when they learn their child has a disability?

- What feelings, thoughts, and difficulties exist through this process?

- How do parents deal with this process?

- What factors facilitate the acceptance process of having a child with disabilities for the parents?

-What is the function of spiritual support among these facilitating factors?

\section{Method}

\section{Research Model}

In this study, the phenomenological research design is used to demonstrate the spiritual coping strategies parents used in the process of accepting their child's disability, how they give meaning to those strategies, and how their spiritual strategies affect the process of accepting a child with disability. 
The phenomenological design is a qualitative research design that helps one understand events, experiences, and cases that cannot be fully grasped, as well as the meanings ascribed to them (Yıldırım \& Şimşek, 2013).

Creswell described phenomenological research as "defining the common meaning of a few people's experiences of a phenomenon" (2013, p. 77). The main aim of phenomenological research is to provide a general description of a personal experience and the meaning of a phenomenon. Therefore, this design was used in the research as the most functional approach to understanding how the participants experienced the phenomena of disability and what their coping mechanisms were.

\section{Participants}

In phenomenological research, individuals or groups who experience and can reflect a focused phenomenon are preferred for the data source. Participants are determined through observations and interviews made in the field by the researcher (Y1ldırım \& Şimşek, 2013).

Sources of data in phenomenological research are those individuals or groups who have experienced the phenomenon in depth and can express themselves when questioned about it. The criterion-based sampling method, appropriate for phenomenological researches, was used to determine the participants here. The main idea of the criterion-based sampling method is to work with situations that meet predetermined criteria. The criteria may be generated by the researcher or a previously prepared list of criteria may be used (Patton, 2001). The criteria in this research are for parents: to have at least one child with a disability, to have a report from a hospital and Guidance and Research Centre (RAM) about the disability, and to provide special education for the child.

The participants are 17 parents, who have at least one child with disabilities and their child's disabilities were limited to diagnoses of physical retardation, mental retardation, and/or autism. Participants' demographic data are presented in Table 1. 
Table 1

\begin{tabular}{ccccccc}
\multicolumn{2}{c}{ Demographic Data } \\
Code & Parent & Child's Disability & $\begin{array}{c}\text { Number of } \\
\text { Children }\end{array}$ & $\begin{array}{c}\text { Rank of } \\
\text { Disabled Child }\end{array}$ & $\begin{array}{c}\text { Years } \\
\text { Married }\end{array}$ & $\begin{array}{c}\text { Age When } \\
\text { Child was Born }\end{array}$ \\
\hline K1 & Mother & Mental & 3 & 3 & 18 & 18 \\
K2 & Mother & Physical \& Mental & 4 & 1 & 22 & 26 \\
K3 & Mother & Mental & 2 & 2 & 18 & 20 \\
K4 & Mother & Physical \& Mental & 2 & 1 & 13 & 21 \\
K5 & Mother & Physical & 2 & 1 & 18 & 18 \\
K6 & Mother & Mental & 2 & 2 & 19 & 32 \\
K7 & Mother & Mental & 3 & 3 & 50 & 23 \\
K8 & Mother & Physical & 2 & 1 & 24 & 25 \\
K9 & Father & Physical & 2 & 2 & 37 & 20 \\
K10 & Mother & Physical & 3 & 3 & 15 & 15 \\
K11 & Mother & Mental & 2 & 2 & 21 & 22 \\
K12 & Mother & Physical \&Mental & 3 & 3 & 18 & 24 \\
K13 & Mother & Autism & 1 & 1 & 21 & 36 \\
K14 & Mother & Physical \& Mental & 2 & 2 & 32 & 24 \\
K15 & Mother & Autism & 3 & 3 & 35 & 28 \\
K16 & Mother & Physical \&Mental & 5 & 4 & 11 & 19 \\
K17 & Mother & Physical & 2 & 1 & & 24 \\
\hline
\end{tabular}

\section{Data Collection Method}

The research data was obtained using the interview technique, one of the methods of qualitative research data collection. Being the most commonly chosen data-gathering tool in qualitative research, the goal of the interview technique is to understand the ideas through the perspective of the individual by means of entering their inner world (Patton, 2001). In other words, the interview technique is a way to understand people's perceptions, interpretations, definitions of reality, and ways they are constructed (Punch, 2011). Establishing an interactive environment based on empathy with the participants being interviewed is essential during the research process. In such an environment, individuals can reflect upon their lives and express meanings they hadn't realized or thought extensively of before. (Yıldırım \& Şimşek, 2013) According to Karasar (2004), the interview technique enables direct verbal interaction between individuals, flexibility in conforming to momentarily changing conditions, applicability to those who are illiterate, instantaneous feedback mechanisms, obtainment of in-depth information, and a high percentage of answered questions.

In this study, the semi-structured interview method was used to be able to theorize how parents accepted the concept of their child being disabled and what spiritual coping strategies they used in overcoming the difficulties faced during this process. 
The semi-structured interview method is often preferred in pedagogic studies due to its specific level of standards and flexibility offered to the researcher (Y1ldirim \& Şimşek, 2013) The literature was reviewed while preparing the semi-structured interview form after the pre-interviews had been performed on the parents with a disabled child. The questions on the prepared interview form were reviewed by three experts, and a pilot implementation was made with the revised questions as per the experts' opinions. Following the pilot implementation, the research was carried out using the finalized semi-structured interview form.

The researchers of this study work in counseling research and rehabilitation facilities; thus, they have field experience in special education. They carried out the research on parents with disabled children who were being helped in their own institutions, which allowed the researchers to have multiple observations and interview experiences regarding the lives of the participants.

The semi-structured interview form, which was developed in the context of this study, consists of two parts. The first part contains questions regarding participants' demographic information (current age, how long they've been married, number of children, number of disabled children, which child is disabled, etc.). The second part contains questions to help theorize the difficulties parents experienced when they learned that they have or would have a disabled child, the people they sought support from against the difficulties faced, and how they coped with problems (see Appendix 1).

\section{Data Analysis and Interpretation}

The semi-structured interviews that were carried out in order to help theorize the difficulties parents with disabled children face and how they cope with these spiritually were voice recorded. This was followed with transcriptions of the recordings and a phenomenological analysis using the MAXQDA 11 package software. Data analysis in phenomenological research is used to uncover experiences and their meanings. During the data analysis process of this study, Giorgi and Giorgi's (2008) descriptive phenomenological analysis method was followed. Because descriptive phenomenological analysis primarily receives descriptions while secondarily regarding interpretations, it brackets all previous information regarding the researched phenomenon and focuses on how the individual experiences that phenomenon to reach its core. Therefore, data-based coding was carried out in this study in order to reach the core of the phenomenon, as opposed to using pre-defined codes obtained from the literature. 
After transcribing the study's raw data, the researchers read both the transcribed texts and listened to the voice recordings multiple times to try and familiarize themselves with the data. The data was analyzed through the coding process simultaneously by three researchers in order to eliminate discrepancies in coding and to provide integrity.

These data-analysis processes were followed in accordance with Giorgi and Giorgi's (2008) descriptive phenomenological analysis: (a) Read all raw data with a phenomenological attitude. At the beginning of the research process, the researchers defined thoughts, judgments, and values related to spiritual coping; they bracketed them and retained these perceptions at every stage of the process. Therefore, during the interviews with the participants, they didn't use any channeling questions that directly or indirectly expressed the form of their spiritual coping regarding how they were coping with or had overcome the situation. Also, during the data coding process, three different researchers independently coded the data according to word, sentence, and paragraph units. The coding was carried out based on the raw data, themes, and subthemes identified in the prospect of mutual concepts and expressions. (b) Distinguishing the units of meaning that point to different aspects of the whole. In line with this study, focus was given to meaningful emotions, thoughts, behaviors, and concepts; these have been noted within the text. (c) Theorizing the psychological significance of the units of meaning. These units, which have higher psychological concentrations of meaning, were identified, and the meaningful phrases were repeatedly read in order to contextually put them in a way that expresses a broader meaning. Within this scope, the units of meaning have been conceptualized as the difficulties participants' faced while accepting the concept of disability, coping strategies, and religious coping strategies, thus enabling more general units of meaning. (d) Putting forth the process of experiencing the phenomenon into a general structure. Individual structural descriptions have been set forth by synthesizing psychological units of meaning that have meaning in the participants' lives and by making a brief chronological description. Unvarying properties were detected by comparing individual structural descriptions for each participant so as to demonstrate the essential features that represent the essence of the phenomenon. Understanding the participants' experiences during the process and the types of difficulties they faced is important for revealing how they spiritually cope with the concept of disability. Therefore, first demonstrating the things experienced then the coping sources was deemed essential in terms of understanding the essence of the phenomenon while revealing the findings.

Strategies for collecting in-depth information, expert review, and participant confirmation were used in this study to provide validity. Data analysis was checked by two faculty members, and the findings were confirmed by the participants. The 
purposeful sampling method was used, parents' statements were described in detail, and direct quotations were frequently included in order to provide transferability. Data were collected using an audio recording device, uniformly coded, and associated with the results in order to provide consistency. Additionally, two faculty members reviewed and compared their judgments, comments, and recommendations with the raw data in order to provide verification (Y1ldırım \& Şimşek, 2011).

\section{Findings}

\section{Difficulties in the Process}

Starting from the moment when the parents learned that their children are disabled or were going to be disabled, they experienced feelings of "shock and devastation." Participant K6 described this feeling as "...a chill ran down my back, I felt terrible and cried for days." K13 expressed, "My husband did some research. I had never seen him like that before, and when he learned the truth he was devastated. In other words, our life became upside-down." Families described their feeling as "nonattributive." K3 explained: "I'm told my child will have some developmental delay. Actually when compared to my elder son, I could tell the difference. However, for doctors to say "do not compare your children with each other," I could not concede the fact; I realized dimly, but actually I could not face the truth"

K10 stated, "Well, I could not imagine that my child would be disabled, I don't know why, maybe because it's my child." Some families said they experienced a "fear of loss," as they had been told that their children could die at any time.

Realizing that they don't have a healthy child as had been expected and that both the education and treatment process is slow, families felt "disappointed." K13 explained this disappointment as: "To tell the truth, I was discouraged because I had been longing for a child. It meant that my dreams would not come true." From time to time, families realized "self-blame" for their child's disability. For example K1 stated, "I looked for someone to blame; I blamed myself. What had I done wrong to deserve this...? I mean, why? I still have some reasons. Sometimes I face the truth, yet sometimes I just can't."

One of the recurring concepts used by families is the concept of loneliness. K10 expressed this experience as "I can't tell you what I lived through. I suffered a lot; I could not go outside... I went through great pain all by myself." K12 expressed the "inefficacy of paternal support" by saying, "Only my husband was by my side, but I can't tell if he supported me or not. Because he is a very aggressive person, he did 
more harm than good; I was all alone." K7 described the "negative influence of the neighborhood" by saying, "There were people making fun of my child, even my brother teased, asking, 'Why doesn't it talk?'... I was upset but I could say nothing." K9 expressed the lack of support with these words: "Everybody seemed to care at first, but nobody cares actually."

While the families struggled on a daily basis for their children, they also felt concern for the future. Certainly, this concern arises from the fear of dying before their children. Some families described this anxiety with these prayers "May they not be all alone when I'm gone," and "I pray to God to not suffer after my child's death, I could not stand that. However, I would not want to leave them alone if I died first."

K17 described this difficult situation and the feeling of "despair" with these words: "... I felt as if I was in a deep well, as if there was no salvation." K13, meanwhile, stated, "He (my husband) was devastated especially at first, I had never seen him like that before. Even though he had suffered many difficulties in his life before, it was hard to witness the man's helplessness." It is possible to summarize the difficulty of the process with K10's sentences:

The doctor said that there was a problem in the brain ventricles of the child that would make it impossible for them to walk or talk. He said that there was nothing that could be done, thus our hands were tied. I was shocked, I said that my child began talking like other kids and had no problem with language, but the doctor said my child could only say "father" and "mother," that it was impossible for them to form a sentence or do any physical activity; there was nothing we could do about it. Even if we saw other doctors in Turkey or in other countries, it would be impossible for us to change this truth. I was ruined, I felt like Ankara had fallen down and I was trapped under the debris.

\section{Coping Strategies/Resources}

As can be seen from these summarized concepts and citations, families face so many difficulties in the processes of having a disabled child, accepting the phenomenon, and caring for the child; they are in pursuit of how to cope with these difficulties. Among the positive coping methods are expert support obtained with the explanations of doctors and educators, family support, support from the social environment and other families with disabled children, rationalization, peace in knowing that they doing their best, anxiety and relief with the ever-growing information about the process, and looking to the future with hope. On the other hand, they had adopted some negative coping mechanisms, such as blaming and inhibiting the development of the child by failing to differentiate themselves from the disabled child, thus creating a dependent life style. To give an example regarding expert support, K6 stated, "We had a doctor 
when we first started coming here. I do not remember his name right now, but I came here and we had a meeting. I talked to him. We also had a psychologist, and I felt relieved after I had spoken with him." Family support is extremely important in overcoming the difficulties in the process. K5 described the support provided by her partner saying, "The greatest factor that made me accept the process is my spouse's support. We are a close-knit family, and maybe that's why we are overcoming our problem more easily..." K15 said, "No one else was there for me except the children. Their father had fallen sick and the children took care of him," while explaining the support provided by her children. Meanwhile, K4 indicated the support provided by her mother, saying “...there have been enormous difficulties encountered through the process, but my biggest fortune was that my mother was there for me. She could be the one who made it possible for me to get over it quickly..." K14 also quoted the support from her mother by saying, "... To this day, my mother has always given me great support." Environmental support has also been indicated as a significant concept through the coping process. Regarding this matter, K11 said, “...wherever I went, thank God, no one differentiated my child from their own. They approached my child with love.” K4 stated, “...all my neighbors and relatives provided great support. They couldn't do enough for us, and I cannot make it up to them, all the good they've done. May God bless them all." As implied in the quotes above, support from experts, family, and the environment are found to have essential functions in the lives of parents with disabled children in that it helps them to not feel alone and to overcome the difficulties encountered through the process.

Some participants have been found to rationalize their lives in order to be able to accept having a disabled child and deal with the situation. Regarding this matter, K4 said, "I thought it might happen. This is life, and anything can happen to anyone at any time. We need to learn how to live with it."

Being closely related to psychological resilience and psychological health, hope is one of the most-talked about concepts in the participant interviews. Regarding this concept, K13 expressed her feelings by saying, "Because something is bound to happen, I feel in my heart, even if my child has epileptic seizures, everything will finish after this seizure ends. Even if my child has a delayed understanding, he will be like a normal child and we will catch up to his peers." K2 said "I still believe he will get better. Maybe his siblings will help, maybe he will get better. I am expecting something good to happen. I swear to God, I am expecting something good to happen. Maybe he will get better after he goes into the program. Someday, if I see that something good happens... I hope he gets better." This concept of hope, which can be seen in the statements of K13 and K2, is thought to function as a temporary coping process, whereas it also causes delays in the acceptance process. 
Following the daily routine, which refers to continuing the usual daily life, is also considered as an effective way of coping with difficulties. K5 indicated that they had kept on living their usual life with these sentences:

I mean we went everywhere from weddings to mawlids (celebrations of Prophet Muhammed's birthday). We went all of them together with Gamze. We did not put any limitations on ourselves. Now that she is at this age, she stays at home with her sibling, and we, my husband and I, go out. Yet, we used to go everywhere we wanted to go together.

Families who are inclined to cope with difficulties by blaming have been found to blame health professionals for not showing adequate interest, for not providing information, for speaking hopelessly, and for their manner of speaking. This method can be seen in K14's statements:

Of course, we have consulted a doctor for physical treatment, but he also didn't give any hope. "This child would not be able to sit. This could be a muscular disease; his muscles could break down and he could die eventually." I mean he told negative things.

$\mathrm{K} 8$, one of the parents who were unable to be apart from the child to create a dependent life style in order to cope with the difficulties tells her own situation with these sentences:

I have been doing everything she needs, considering that she will die in a short while. Then, Nimet became an indispensable part of me. When I go somewhere without Nimet by my side, I start to look around with blank and silly eyes. Sometimes, I wonder whether people are asking "Why is this woman looking around like that?" or not. I do not know whether this is some kind of addiction or what.

\section{Spiritual Coping}

In order to overcome the difficulties encountered while accepting the disability and providing the disabled children with care, families have been found to adopt spiritual coping strategies along with the coping styles above.

The concepts that families mention about religious coping are "accepting what comes from God" and "destiny," which are contained in the theme of acceptance. About accepting what comes from God, K9 said, "We are people who believe, and because of our belief we accept what God has given us. I was the person who is the one in a thousand. God saw this as appropriate." K14 stated, "I told myself, 'My God, don't take him away from me. I will look after him even he is disabled.' I prayed like that." K10 voiced, "You stand it because it is from God. You couldn't stand anything like this if it were from people. You say it is from God and you accept it." Another 
repeated concept is destiny. K6 said, "I didn't look for anyone to be guilty. I say it is from God. It was my fate. God wrote him into my destiny..." K12 expressed, "I'm only saying this was my destiny. God wrote this for me..." These words show that they saw their children with disabilities as a condition that God fated for them. As seen in these statements, the participants intend to accept what God has given them by describing the disability phenomenon to be what God has seen as appropriate for them.

In accepting the disability phenomenon, "giving spiritual meaning" is often used. Families are seen to review their new lives and consider having a child with a disability as an examination, penance, fear of God, and an entrustment from God. Of the participants who see this as an examination, K16 said, "I didn't ask why this has happened to me; my God has granted this to me. I am going to accept it. God gave me it because I can carry this burden." This does not overestimate the difficulty and also develops self-confidence. K2 stated, "He is my examination, sir, my examination. Thank God He gave me this. He saw this is appropriate. My examination is with him. Let God make my examination easy for me." This perspective shows they have accepted the examination and are coping with the process and difficulties. K1 voiced, "I'm afraid of losing all the time with this, because I don't know if Zeynep will help me pass the exam, because sometimes it is too hard to have patience." K1 sees her child's disability as an examination, but because of the difficulty of passing the exam, she has also expressed fear.

K14, who believes children with disabilities are given by God as an opportunity to "purify through penance" because of past sins said, "I have connected this to an abortion I had. I regretted and wished for forgiveness so much that I see this as my reason for forgiveness. Maybe this thought gives me more strength to cope." K10 also hoped to be forgiven by looking after her disabled child because of her past abortions, saying "I blame myself for this. I had many abortions... So I thought about those."

Fear of God is seen in some participants during the process of accepting children with disabilities. K12 said, "God knows I went to the doctor at first in the pregnancy. The doctor said that he should perform an abortion because the child will die soon after birth. I said she can die soon after birth, but either way I will take her in my arms. The child is now kicking in my belly, really she kicks so beautiful. God does not want an abortion;" this makes it easier to accept the process and the child, giving meaning instead of doubt.

Seeing the child with a disability as an entrustment from God supports the acceptance process in parents. K5 said "I say this is something that comes from God, an entrustment from God. I am going to look after this entrustment in the best way," and attributed a higher value to the child. K12 said, "So my God gave me this, and I can show him to 
everyone proudly," and refers to a sense of honor instead of how many parents' feel shame and withdraw from society.

One of the spiritual foundations that facilitates the family's coping is analyzed under the theme trust in God, and at the point where their power is insufficient it is conceptualized as resignation, gratitude, and prayer. Resignation, while giving people strength by making them feel to the utmost, also bears the nature of a prayer that reduces anxiety. Regarding this subject, K16 revealed her inner peace by saying, "As long as my God gives me strength and power, I will continue. I then leave the rest to Him." K7 shows her faith in God by saying:

My husband says that if our child knows what money is and can learn and write telephone numbers, there would be no need for anything else. He says other people would send him to a desert. But I say no, they wouldn't. God is almighty.

Although families have children with disabilities, they are always found to apply the theme of gratitude to God. K5, by comparing her child with disabilities to other children with disabilities, shows her gratitude to God by saying, "We are grateful for what we have. We could also be changing our child's diaper. It could be worse. Such necessities also exist." K11 reveals her gladness both for her child's existence and the joy he brings to their home:

When I learned that my child was going to be born with a disability, I was one-and-ahalf months pregnant. I didn't feel sorry at all. I thought that God had given this to me. Then I gave birth, thank God. I am glad that I gave birth to the baby. He has brought joy to our home.

The same mother makes a difficult process easier by way of showing her gratitude for even the tiniest improvements in her child: "Thank God he is healthy; now he realizes the world around him. He is improving. He can hold his spoon and eat his meal."

The notion of prayer, which is used frequently through the process, helps individuals by reducing loneliness and giving individuals hope. It also improves their psychology by showing them their limitations and, in return, makes them trust in God, the infinite giver. Regarding this issue, K2 said, "I pray that God will ease my task for me." Thus, she reflects the difficulty of the process of caring for a child with disabilities, and by wishing for facilitation from God, she shows her trust in God. Likewise, K11 also stated that she takes strength from her family and friends: "Prayers from my friends and family help me. Both of my parents pray to God a lot for me." 


\section{Conclusion and Discussion}

In-depth interviews were conducted with 16 mothers and one father of disabled children for this qualitative research, which aimed to analyze the difficulties faced during the acceptance process of having a disabled child in the family and the support mechanism used for coping. The obtained data were subjected to phenomenological analysis and divided into three general categories: the difficulty of the process, coping sources, and spiritual coping. The themes of difficulty of the process and coping resources were discussed in order to get a better understanding of the phenomenon of spiritual coping. Difficulty of the process includes the themes of shock/collapse, not attributing, fear of losing the child, disappointment, self-blame, loneliness, lack of paternal support, negative environmental effects, concern for the future, and despair. Coping sources includes the themes of expert support, family support, environmental support, rationalization, hope, keeping up the routines, blaming, and not able to be apart from the child.

In this research, the parents of disabled children were found to often resort to religious/spiritual sources while accepting the concept of disability and overcoming the difficulties faced during the care-giving process. Religion was stated as an important element of support in coping with stressful life events. The rate of referencing religious coping strategies has been stated as $27 \%$ for depression, $14 \%$ for general disabilities, and 34\% for psychosocial disabilities (Burker, Evon, Sedway, \& Egan, 2004). Care givers who use religious/spiritual coping in the process of providing care to disabled individuals have been found to establish better relationships with disabled patients; religious coping is also associated with lower levels of depression (Chang, Noonan, \& Tennstedt, 1998). Additionally, using religious sources has been indicated as important for professionals working with people who have disabled family members, as well as in the design process of intervention programs for religious families (Johnstone et al., 2007; Rodriguez, Glover-Graf, \& Blanco, 2013; Tarakeshwar \& Pargament, 2001).

Spiritual coping resources, which forms the center of this research, has been analyzed under three themes. The theme of acceptance was discussed under the sub-themes of destiny and accepting what comes from God. The theme of providing spiritual meaning was discussed under the sub-themes of examination, repentance, fear of God, and an entrustment from God. The theme of trust in God was discussed under the sub-themes of resignation, gratitude, and prayer.

All of the interviewed parents stated that they had accepted their child with disability. The belief that all these are given by God is important in this acceptance. They are understood to see the difficulties they face as a part of their fate. In parallel 
with the research, Herken et al. (2000) and Kara (2008) stated that families consider the disability of their children as their destiny. Similarly, regarding the theme of submission to what comes from God, Kara's (2008) research defined the theme as a belief that parents of disabled children don't think God has been unfair with them and still continues to love them.

Parents feel the need to interpret the difficult process they experience and ease that process according to the meaning they attribute to the situation (Ayten et al., 2012). Pargament and Brant (1998) stated that people attribute positive religious meaning to difficult situations and connect them to God's will; this cognitive re-structuring, in turn, eases acceptance. Kara (2008) stated that $67 \%$ of families consider a disabled child as a test. This study has found that families consider having a disabled child as their test in this world on the road to reaching heaven and for God's sake. Some parents believe they have a disabled child because of their past sins (i.e., abortion) and the situation they face now is an opportunity for purification or an acceptance of their repentance. This research has also found that considering disabled children as an entrustment from God is important in accepting having a disabled child and overcoming the difficulties experienced in the process of caregiving. Parents who interpret the process of providing care to a disabled child as protecting God's entrustment are understood to not face difficulties in accepting the child's condition and to demonstrate high motivation in the child's care and education. Similarly, Gören's (2015) study found that parents of disabled children consider them to be entrusted from God. Also the theme of fear of God is among the primary concepts expressed in this study. Fear of God has been found to be an important support and reference point in deciding to give birth to, accepting, and providing care to a disabled child.

Humankind tends to turn to religious coping strategies, feeling the need to seek refuge in God or a powerful authority in helpless and desperate conditions (Burker et al., 2004). Individuals who have this sense of submission will not waver even in the most difficult conditions because they think the events they are going through all come from God and are just a test (Altıntaş, 2015). This study has found that parents experienced various difficulties from the moment they first faced the disability situation, and they sought refuge in God by means of prayer, praise, and reliance (namely trusting God) so their acceptance process has been eased. Parents who showed reliance were found to experience inner peace and a reduced anxiety about the future because they were doing their best.

Praise is used in the sense of showing thankfulness for and feeling content with their goodness and blessings (Kalkan-Oğuzhanoğlu \& Özdel, 2005). According to Ayten et al. (2012), who stated that praise is closely related to being aware of the 
experienced moment, being conscious of praise enables the individual to keep one's joy of life alive even in difficult conditions. This study has found that despite having a disabled child, parents did not stop voicing the theme of praise. Some parents were seen to compare their child with other disabled children and praised God, while some of them considered the small progresses in the process of caring for their disabled child as occasions for praise, thus making the the process easier. When examining this study and other studies dealing with the theme of praise, the act of praising can be said to be about seeing the glass half-full and focusing on the positive part of the phenomenon.

Prayer is an active coping strategy (Pargament \& Brant, 1998). People look for refuge and harbor in trust when facing lethal diseases, difficult living conditions, or situations that feel completely helpless. With the help of prayer, parents seek refuge in God against the desperation, shock, and anxiety about the future they experience to alleviate their concerns. In Kara's (2008) study, $96 \%$ of parents with disabled children stated that praying has a positive effect on their psychological state; $94.7 \%$ stated that they seek help from God by praying in times of trouble. The theme of prayer has been noted to be repeated often during the interviews with parents. It is understood from parents' statements that parents who pray talk with God and reduce their loneliness, foster their hopes and reflect their trust in God through prayer, and strengthen themselves psychologically.

When examining the core of the study, the parents can be observed to consider having a disabled child, in their own words, as "a ticket to heaven." Looking at the situation this way eases the acceptance process.

The results obtained from this research regarding coping mechanisms against the concept of disability have been raised in the findings section with a focus on the theme of spiritual sources and put forth in the discussion section in terms of its relations with other discussions in the literature. However, this research is seen to have certain limitations, considering both the broadness of the subject and the study group. New research done by field experts and academicians will contribute to the enrichment of this subject. The following suggestions may be submitted in this regard.

The participants of this study consisted of parents who had to cope with the concept of disability. However, studies can be carried out which make it possible to reflect the views of other parents. Studies can be done addressing the individual forms of spiritual coping. Individuals with disabled siblings experience both the difficulty of having a disabled sibling and looking after them; they can also be emotionally neglected and have to grow up too quickly due to parents being obligated to spend more time and effort with their disabled sibling. Future studies carried out about 
siblings are expected to provide important contributions to the field. In one possible study addressing parents without disabled children, their perceptions and imaginings of the concept of disability can be analyzed, and the findings can be compared. The process of mothers' and fathers' interpretations of the concept of disability can also be compared and analyzed. Mixed-pattern research, instead of qualitative or quantitative research, may enable a versatile understanding of the phenomenon. The experiences of parents who have children with different disabilities can be compared and analyzed. The majority of studies done in the field are observed to be based on religious psychology. However, as one of the most talked about and studied fields, spiritual counseling is thought to be a therapeutic field that requires professional psychology/counseling skills, and it is important for experts in the field to focus on these subjects. Disability is a phenomenon which is difficult to cope with, and subjects and themes that strengthen religious coping may be included, depending on their preferences in family education programs and counseling studies.

\section{References}

Altıntaş, S. (2015). Depresyon ile dinsel başa çıkmak mümkün mü? [Is it possible religious coping with depression?]. The Journal of Academic Social Science Studies, 36, 403-428. http://dx.doi. org/10.9761/JASSS2954

Ayten, A. (2012). Tanrıya sığınmak: Dini başa çıkma üzerine psiko-sosyal bir araştırma [Taking refuge to God: A Psychosocial research on religious coping]. İstanbul, Turkey: İz Yayınc1lı.

Ayten, A., Göcen, G., Sevinç, K., \& Öztürk, E. E. (2012). Dini başa çıkma, şükür ve hayat memnuniyeti ilişkisi: Hastalar, hasta yakınları ve hastane çalışanları üzerine amprik bir araştırma [The relations of religious coping, gratitude and life satisfaction: A case study on patients, patient relatives and hospital staff]. Dinbilimleri Akademik Araştırma Dergisi, 12(2), 45-79. Retrieved from http://dinbilimleri.com/Makaleler/1437934401_1202030763.pdf

Batlaş, A., \& Batlaş, Z. (1998). Stres ve başaçıkma yolları [Coping with stress]. İstanbul, Turkey: Remzi Kitabevi.

Billings, A. G., \& Moos, R. H. (1981). The role of coping responses and social resources in attenuating the impact of stressful life events. Journal of Behavioral Medicine, 4, 139-157. http://dx.doi.org/10.1007/BF00844267

Chang, B., Noonan, A. E., \& Tennstedt, S. L. (1998). The Role of religion/spirituality in coping with caregiving for disabled elders. The Gerontologist, 38(4), 463-470. Retrieved from http://gerontologist.oxfordjournals.org/content/38/4/463.full.pdf

Cox, T., \& Ferguson, E. (1991). Individual differences, stress and coping. In L. C. Cooper \& R. Payne (Eds.), Personality and stress: Individual differences in the stress process (pp. 7-30). Oxford, England: John Wiley \& Sons.

Creswell, J. W. (2013). Nitel araştırma yöntemleri: Beş yaklaşıma göre nitel araştırma ve araştırma deseni [Qualitative inquiry and research design: Choosing among five approaches]. (M. Bütün \& S. B. Demir, Trans. Ed.). Ankara, Turkey: Siyasal Kitabevi. 
Durukan, İ., Erdem, M., Tufan, A., \& Türkbay, T. (2010). Otistik spektrum bozukluğu olan çocukların annelerindeki baş etme tutumları ve depresyon ile anksiyete düzeyleriyle ilişkisi [Coping strategies and relation of coping strategies with depression and anxiety levels of mothers of children with pervasive developmental disorder]. Çocuk ve Gençlik Ruh Să̆ğğ Dergisi, 17(2), 75-82. Retrieved from http://scopemed.org/fulltextpdf.php?mno=32349

Burker, E. J., Evon, D. M., Sedway, J. A., \& Egan, T. (2004). Religious coping, psychological distress and disability among patients with end-stage pulmonary disease. Journal of Clinical Psychology in Medical Settings, 11(3), 179-193. http://dx.doi.org/10.1023/B:JOCS.0000037612.31730.56

Ekşi, H., Hatun, O., Yavuz Birben, F., KalkanYeni, G., Türk, T., Tozlu Güldal, Ş., \& Ulaş, E. (2016). Yeniden doğmak: Böbrek nakli olan hastaların psikososyal süreçleri [Reborn: Psychosocial processes of patients with renal transplantation.]. Istanbul, Turkey: Nobel Yayınc1lık.

Endler, N. S., \& Parker, J. D. A. (1992). Interactionism revisited: Reflections on the continuing crisis in the personality area. European Journal of Personality, 6, 177-198. http://dx.doi. org/10.1002/per.2410060302

Ergün, S., \& Ertem, G. (2012). Difficulties of mothers living with mentally disabled children. Journal of the Pakistan Medical Association, 62, 776-780. Retrieved from http://www.jpma. org.pk/PdfDownload/3605.pdf

Folkman, S., \& Lazarus, R. S. (1980). An Analysis of coping in a middle-aged community sample, Journal of Health and Social Behavior, 21(3), 219-239. http://dx.doi.org/10.2307/2136617

Folkman, S., \& Moskowitz, J. T. (2004). Coping: Pitfalls and promise. Annual Review of Psychology, 55, 745-774. http://dx.doi.org/10.1146/annurev.psych.55.090902.141456

Giorgi, A., \& Giorgi, B. (2008). Phenomenological psychology. In C. Willig \& W. Stainton Rogers (Eds.), The Sage handbook of qualitative research in psychology (pp. 165-214). London, UK: Sage.

Gören, A. B. (2015). Down sendromlu çocuğa sahip annelerin destek ihtiyaçlarının ve destek kaynaklarının belirlenmesi [Assessing the needs and sources of support of mothers with down syndrome child]. Insan ve Toplum Bilimleri Araştırmaları Dergisi, 4(3), 651-673. Retrieved from http://itobiad.com/article/viewFile/5000138974/5000132219

Hastings, R. P., Kovshoff, H., Brown, T., Ward, N. J., Espinosa, F. D., \& Remington, B. (2005). Coping strategies in mothers and fathers of preschool and school-age children with autism. Autism, 9, 377-391. Retrieved from http://eprints.soton.ac.uk/40187/1/6861339.pdf

Herken, H., Turan, M., Şenol, Ş., \& Karaca, S. (2000). Down sendromlu çocuğu olan anne babaların depresyon düzeyleri ve depresyonla başa çıkma becerileri [Coping strategies and depression levels of mothers and fathers of down's syndrome children]. Çocuk ve Gençlik Ruh Să̆liğl Dergisi, 7, 143-152. Retrieved from http://scopemed.org/fulltextpdf.php?mno=34523

Iş1khan, V. (2005). Engelli çocuğa sahip anne ve babalarda depresyon [Depression in father and mother with disabled children]. Ankara, Turkey: Şefkat Matbaacılık.

Johnstone, B., Glass, B. A., \& Oliver, R. E. (2007). Religion and disability: Clinical, research and training considerations for rehabilitation professionals. Disability and Rehabilitation, 29(15), 1153-1163. http://dx.doi.org/10.1080/09638280600955693

Kalkan-Oğuzhanoğlu, N., \& Özdel, O. (2005). Yaşl11ık, huzurevi ve yaşam yolculukları: Bir psikodrama grup çalışması [The elderly, nursing homes and life voyages: A psychodrama group study]. Türk Psikiyatri Dergisi, 16, 124-132. Retrieved from http://turkpsikiyatri.com/C16S2/ yaslilikHuzurevi.pdf 
Kaner, S. (2004). Engelli çocukları olan ana babaların algıladıkları stres, sosyal destek ve yaşam doyumlarinin incelenmesi [Perceived stress, social support and life satisfaction in parents with disabled children]. (Scientific Research Projects, Ankara University). Retrieved from http:// acikarsiv.ankara.edu.tr/browse/498/798.pdf

Kara, E. (2008). Zihinsel engelli çocukları olan ailelerin çocuklarının durumunu dinî açıdan değerlendirmeleri [The Parents having mentally retarded children and their assesment of their children's situation in terms of religion]. Ondokuz Mayıs Üniversitesi İlahiyat Fakültesi Dergisi, 26(26-27), 317-331. Retrieved from http://dergipark.ulakbim.gov.tr/omuifd/article/ view/5000073390/5000067649

Karagöz, S. (2010). Otistik çocukların anne babalarında anlamlandırma ve dini başaçıkma [Search for meaning and religious coping in parents of autistic children] (Master's thesis, Marmara University, Istanbul, Turkey). Retrieved from https://tez.yok.gov.tr/UlusalTezMerkezi/

Karasar, N. (2004). Bilimsel aştırma yöntemi [Scientific research method]. Ankara, Turkey: Nobel Yayıncilik.

Kissinger, H. (2006). Coping is the means, resilience is the outcome. In C. B. Goode., T. Goode \& D. Russell (Eds.), Help kids cope with stress \& trauma (pp. 1-12). Whitney, TX: Inspired Living International.

Koenig, H. G., Larson, D. B., \& Larson, S. S. (2001). Religion and coping with serious medical illness. Ann Pharmacother, 35, 352-359. http://dx.doi.org/10.1345/aph.10215

Koenig, H. G., Pargament, K. I., \& Nielsen, J. (1998). Religious coping and health status in medically ill hospitalized older adults. Journal of Nervous \& Mental Disease, 186(9), 513-521.

Lazarus, R. S. (1990). Theory based stress measurement. Psychological Inquiry, 1(1), 3-13. http://dx.doi.org/10.1207/s15327965pli0101_1

Miltiades, H. B., \& Pruchno, R. (2002). The Effect of religious coping on caregiving appraisals of mothers of adults with developmental disabilities. The Gerontologist, 42(1), 82-91. Retrieved from http://gerontologist.oxfordjournals.org/content/42/1/82.full.pdf

Mirsaleh, Y. R., Rezai, H., Khabaz, M., Afkhami Ardekani, I., \& Abdi, K. (2011). Personality dimensions, religious tendencies and coping strategies as predictors of general health in Iranian mothers of children with intellectual disability: A Comparison with mothers of typically developing children. Journal of Applied Research in Intellectual Disabilities, 24, 573-582. http://dx.doi.org/10.1111/j.1468-3148.2011.00639.x

Muller, L., \& Spitz, E. (2002). Multidimensional assessment of coping: Validation of the Brief COPE among French population. L'encéphale, 29(6), 507-518. Retrieved from http://ncbi.nlm. nih.gov/pubmed/15029085

O'Connell, T., O'Halloran, M., \& Doody, O. (2013). Raising a child with disability and dealing with life events: A mother's journey. Journal of Intellectual Disabilities, 17(4), 376-386. Retrieved from https://ulir.ul.ie/bitstream/handle/

Pargament, K. I., \& Brant, C. R. (1998). Religion and coping. In H. G. Koenig (Ed.), Handbook of religion and mental health (pp. 111-128). San Diego, CA: Academic Press.

Pargament, K. I. (2001). The psychology of religion and coping: Theory, research, practice. New York, NY: Guilford Press.

Patton, M. Q. (2001). Qualitative research and evaluation methods (2nd ed.). Thousand Oaks, CA: Sage. 
Punch, K. F. (2011). Sosyal araştırmalara giriş: Nicel ve nitel yaklaşımlar [Introduction to social research: Quantitative and qualitative approaches] (D. Bayrak, H. B. Aslan \& Z. Akyüz, Trans.). Ankara, Turkey: Siyasal Kitabevi.

Rodriguez, V. J., Glover-Graf, N. M., \& Blanco, E. L. (2013). Conversations with God: Prayer and bargaining in adjustment to disability. Rehabilitation Counseling Bulletin, 56(4), 215-228. http://dx.doi.org/10.1177/0034355213477477

Sevim, Z. (2011). Aileler ve özel eğitimcilerin zihinsel özürlülüğe bakışı (Şehit Aliborinli İlköğretim Okulu ve İş Okulu örneği) [View of families and special education to mental disability (A case study: Şehit Ali Borinli Elementary School and Business School)] (Master's thesis, Sakarya University, Istanbul, Turkey). Retrieved from https://tez.yok.gov.tr/UlusalTezMerkezi/

Skinner, E. A., \& Zimmer-Gembeck, M. J. (2007). The development of coping. Annual Review of Psychology, 58, 119-144. Retrieved from https://pdx.edu/sites/

Stephen Gallagher, S., Phillips, A. C., Lee, H., \& Carroll, D. (2015).The Association between spirituality and depression in parents caring for children with developmental disabilities: Social support and/or last resort. Journal of Religion \& Health, 54, 358-370. Retrieved from https:// ulir.ul.ie/bitstream/handle/

Şardağ, S. (2010). Zihinsel engelli çocuğa sahip annelerin stresle başaçıkma tarzları ve aile sosyal desteğinin evdeki uyumların yordaması [Prediction of marital adjustment by ways of coping with stress and family social support in mothers of mentally retarded children] (Master's thesis, Ege University, Izmir, Turkey). Retrieved from https://tez.yok.gov.tr/UlusalTezMerkezi/

Tarakeshwar, N., \& Pargament, K. I. (2001). Religious coping in families of children with autism. Focus on Autism and Other Developmental Disabilities, 16, 247-260. http://dx.doi. org/10.1177/108835760101600408

Uğuz, Ş., Toros, F., İnanç, B. Y., \& Çolakkadıoğlu, O. (2004). Zihinsel ve/veya bedensel engelli çocukların annelerinin anksiyete, depresyon ve stres düzeylerinin belirlenmesi [Assessment of anxiety, depression and stress levels of mothers of handicapped children]. Klinik Psikiyatri, 7(1), 42-47. Retrieved from http://faydaozelegitim.com.tr/wp-content/download/zihinselvebedensel.pdf

Yıldırım, A., \& Şimşek, H. (2013). Sosyal bilimlerde nitel araştırma yöntemleri [Qualitative research methods in social sciences]. Istanbul, Turkey: Seçkin Yayıncılık.

\section{Appendix 1}

\section{Interview Form}

\begin{tabular}{|c|c|}
\hline Date of Interview: & Time for Interview: \\
\hline Name-Surname / Nickname: & Mother/Father? \\
\hline Years Married? & Number of Children? \\
\hline Age when became a parent? & Birth order of the disabled child? \\
\hline Diagnosis of the child's disab & \\
\hline
\end{tabular}


1. How did you learn your child has a disability?

2. What did you feel when you learned you would have a child with a disability?

- What were your first feelings?

- Who were you with? Who supported you and how?

- What can you say about your spouse's approach in this process?

3. What were the first thoughts that came to your mind when you learned you would have a child with a disability?

- Why does the child have a disability?

- How will the life of the child be affected? How will s/he cope with it? What is $\mathrm{s} /$ he going to do now?

- Did you feel anger (why me)?

4. What things facilitated your conceding to your child's disability?

- What made you feel good?

- Family, spouse, friends, economical support, etc.?

- Values/ religion, beliefs, prayers, etc.?

- Did these factors influence the child's development?

5. What would you say when comparing your approach to your children with and without disability?

- Were there any differences?

- Acceptance problem/more support?

- Approach of the child without disability?

- How did you solve problems on this issue?

6. How did people react from your social environment?

- What did they say to you, how did they behave?

- How did their behaviors make you feel?

- How did you cope with problems related to this issue?

- What made you feel good?

7. How were your close friends and relatives affected after you had a child with a disability?

- Did they change?

- Spouse's reactions? (Supportive, negligent, inhibitive, etc.?) 
8. When did you start to provide special education for your child?

- If late, why?

9. Beyond everything we've talked about, do you have anything to add for us to understand you and your experiences?

Thanks for participating in this study. 
8ु. SPIRITUAL PSYCHOLOGY AND COUNSELING 